\title{
Analysis of Escherichia Coli Contamination in Karang Mumus River, Samarinda City
}

\author{
Andi Daramusseng $^{1 *}$, Syamsir $^{1}$ \\ ${ }^{1}$ Department of Environmental Health, Universitas Muhammadiyah Kalimantan Timur 75243, Indonesia \\ *Corresponding author. Email: andidaramusseng@umkt.ac.id
}

\begin{abstract}
Karang Mumus River is one example of a river that has pollution. The source of pollution comes from the community activities around the river such as dumping garbage and liquid waste into the river and using the toilet over the river. In addition to making the river a waste disposal site, people in the region also use river water for bathing, washing clothes, washing kitchen utensils even for consumption. This is very worrying because it can cause health impacts on the community. The purpose of this study was to analyse the contamination of Escherichia coli bacteria in the Karang Mumus River. The method in this research is observation and laboratory measurement. The analysis technique used is to compare laboratory test results with the Environmental Protection Agency standards. The results of the research showed that the lowest number of Escherichia Coli bacteria was $<30 \mathrm{CFU} / 100 \mathrm{ml}$ and the highest was $2400 \mathrm{CFU} / 100 \mathrm{ml}$. Based on the Environmental Protection Agency's standards that out of 8 sample points, $37.5 \%$ did not meet surface water-full body contact requirements and $100 \%$ did not meet requirements for consumption.

Keywords: Escherichia Coli, contamination, community activities, Karang Mumus River
\end{abstract}

\section{INTRODUCTION}

Rivers as the biggest water supplier cannot be avoided by pollution problems. River pollution is a result of human activities that live around watersheds. In 2015, the Directorate General of Environmental Pollution and Damage Control of the Ministry of Environment and Forestry reported that nearly 68 percent or the majority of river water quality in 33 provinces in Indonesia is heavily polluted [1]. Kalimantan Regional Region is one of the areas with rivers that are categorized as heavily polluted. River pollution that occurs in the Kalimantan region is generally caused by domestic waste disposal into rivers without prior processing, especially in some districts/cities, including Kota Samarinda.

Samarinda City is a city surrounded by many rivers, such as the Karang Mumus River. The number of settlements along the river is one of the causes of the decline in river quality. Communities in the area make the river as a place to build latrines and dispose of garbage and liquid waste [2]. The most dangerous part of all these activities is the presence of pathogenic microorganisms such as Escherichia coli (E. coli) bacteria in rivers. Escherichia coli is a group of bacteria commonly found in the intestines of warm-blooded animals, including humans [3]. Escherichia coli bacteria can cause various diseases if it enters the human body such as diarrheal, urinary tract infections, respiratory diseases, pneumonia, and other diseases [4]. Besides, according to Ingerson and Reid [5] infections can spread in the body (to blood, liver, and nervous system).

People who live along the river have access to clean water so they have access to the river for daily needs such as bathing, washing clothes, washing kitchen utensils and even for consumption. This is very worrying because it can cause health impacts on the community. Escherichia Coli bacteria is the best bacterium for knowing the presence of faecal contamination in water. Besides, it can be used to measure public health risks [6].

Research about the Escherichia coli bacteria in river water has been widely carried out, such as the research of Genisa and Uliandari [7] found in the presence of Escherichia coli bacteria in the Musi River with the highest Escherichia coli around the settlement. Other studies conducted by Hatifah, Anwar and Risva [8] found the lowest number of Escherichia coli bacteria was $150 / 100 \mathrm{ml}$ and the highest was $930 / 100 \mathrm{ml}$. The study was carried out in the watershed of the Bandara Village, so it has not described the overall condition of the Karang Mumus river. Based on this, researchers are interested in analysing the contamination of Escherichia coli bacteria from upstream to downstream in Karang Mumus River, Samarinda City.

\section{METHOD}

The method used in research is field observations and laboratory measurements. This research was conducted in Karang Mumus river, Samarinda City in June - September 2019. Sampling was carried out in the main river as many as 8 points using the Grab Sample. The determination of the sampling point is based on potential sources of pollutants from upstream to downstream where are densely populated settlements. The sample inspection was conducted at the Research and Industrial Standardization Center in Samarinda City, East Kalimantan using the test method based on SNI 19-2897-1992 concerning how to test the microbial contamination, items 2.2. The analysis technique 
used is to compare laboratory test results with the Environmental Protection Agency standards.

\section{RESULTS AND DISCUSSION}

The Karang Mumus River is a tributary of the Mahakam which runs 32,196.3 ha. Karang Mumus River is very important for the life of the surrounding community. The topography of the Karang Mumus River Basin is hilly and also lowland, especially the watershed within Samarinda City. In general, watersheds are used as settlements, types of businesses such as workshops, tofu and tempe manufacturing, agriculture and there are also still in the form of vacant land. The research location can be seen in Figure 1.

\section{Map of Research Location}

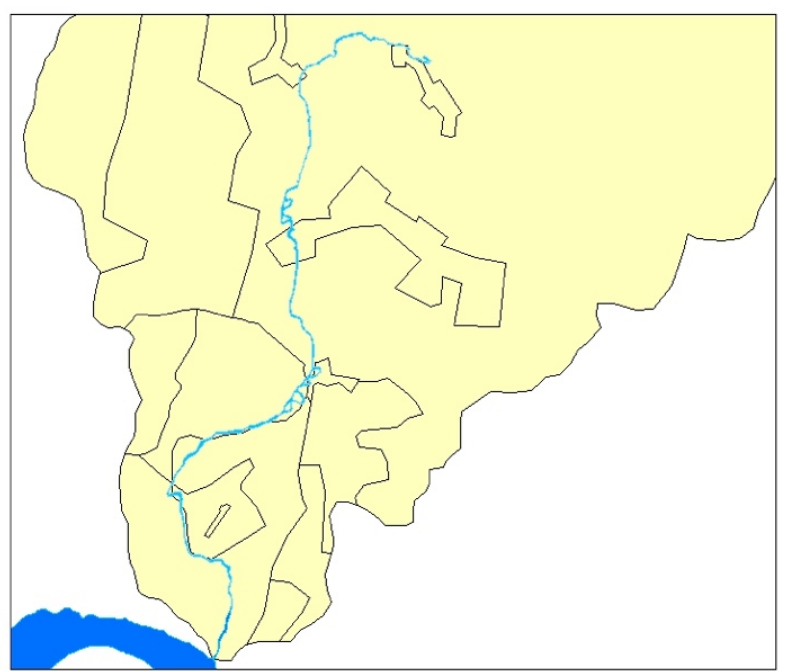

Figure 1 Research Location

A Sampling of the Karang Mumus River water is done at 8 main river points. Consideration of sampling locations based on the presence of potential pollutant sources, namely densely populated settlements. The concentration of E.coli is expressed in the amount of E.coli per $100 \mathrm{ml}$ using the
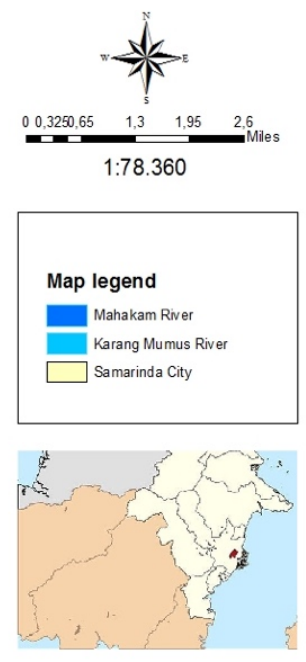

Environmental Protection Agency's standards [9]. The results of the examination of $\mathrm{E}$. coli bacteria parameters in the Karang Mumus River water sample can be seen in table 1 .

Table 1 Measurement results of Escherichia Coli Bacteria in Karang Mumus River, Samarinda City

\begin{tabular}{|lccc|}
\hline \multicolumn{1}{|c}{ Location } & $\begin{array}{c}\text { Measurement } \\
\text { Results } \\
\text { (CFU/100 ml) }\end{array}$ & $\begin{array}{c}\text { E.Coli's Quality Standards } \\
\text { for surface water- full body } \\
\text { contact (EPA, 2004) }\end{array}$ & $\begin{array}{c}\text { E.Coli Quality Standards } \\
\text { for consumption (EPA, } \\
\text { 2004) }\end{array}$ \\
\hline Jembatan Benanga & 430 & & \\
Jembatan Bengkuring & $<30$ & & \\
Perum Griya Mukti & $<30$ & & $0 \mathrm{CFU} / 100 \mathrm{ml}$ \\
Jembatan Gelatik & $<30$ & $235 \mathrm{CFU} / 100 \mathrm{ml}$ & \\
Ruhui Rahayu & 150 & & \\
Jembatan Arif Rahman Hakim & 2400 & & \\
Jembatan S & 280 & & \\
Pelabuhan & 150 & & \\
\hline
\end{tabular}

Source: Primary Data

The results of Escherichia coli measurements carried out in Karang Mumus River, Samarinda City showed that the lowest E.Coli bacteria content in Bengkuring Bridge, Griya Mukti Bridge, and Gelatik Bridge each $<30$ CFU / $100 \mathrm{ml}$ and the highest at Arif Rahman Hakim Bridge was equal to $2400 \mathrm{CFU} / 100 \mathrm{ml}$. From 8 sample points, 37.5\% did not meet the surface water-full body contact requirements and $100 \%$ did not meet the requirements for consumption.
Spatial distribution is also presented to clarify spatial locations of pollution and identify existing activities around rivers. This is necessary for handling the control of the Karang Mumus River pollution. The spatial distribution of Escherichia coli in the Karang Mumus River is presented in figure 2. 


\section{Map of the Distribution of Escherichia coli}

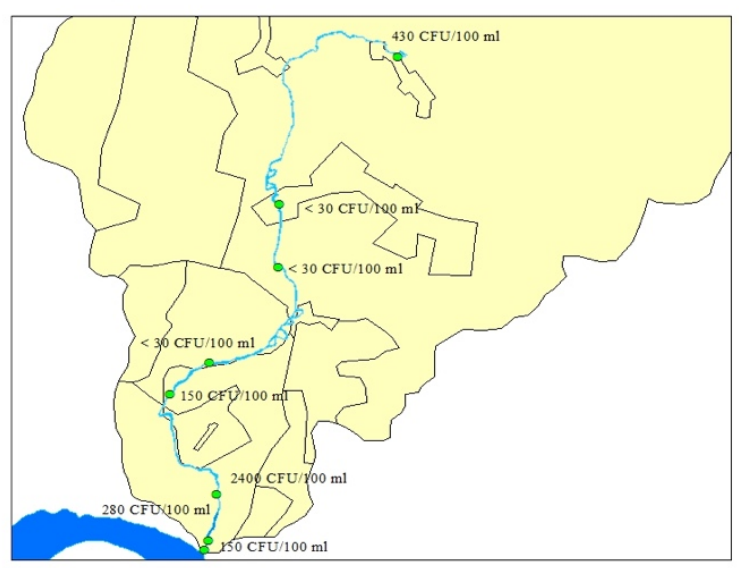

Figure 2 Distribution of Escherichia coli

The presence of Escherichia Coli bacteria in the Karang Mumus River is caused by the presence of settlements with high population density on the riverbanks. Communities living on the riverbanks throw trash and household liquid waste directly into the river without prior processing. Waste is the material that remains after the product is made by the manufacturer and after it is used by consumers [10]. The type of waste generated at the household level and a source of E. coli pollution is diapers. Diapers that contain human waste are thrown directly into the river so that it pollutes the river. Currently, the use of baby diapers continues to increase. Every baby can use four to nine diapers per day. That means the disposal of baby diapers in the river is also increasing [11].

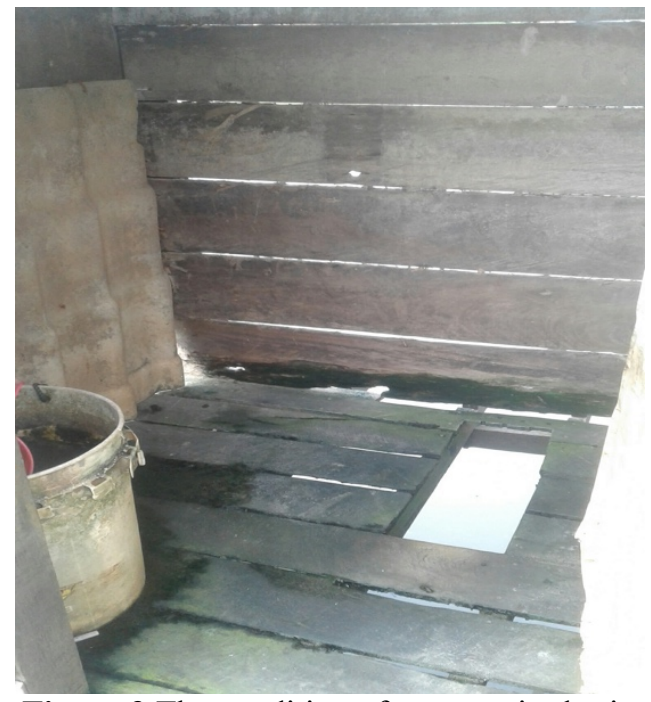

Figure 3 The condition of community latrines on the banks of the Karang Mumus River

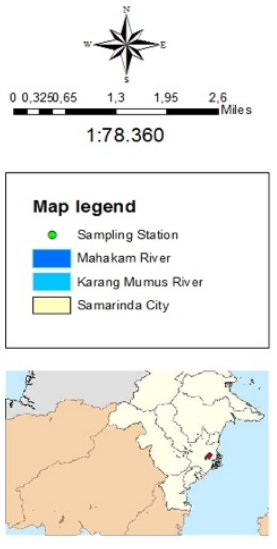

Another factor that most influences the presence of E. coli bacteria in the Karang Mumus River are the ownership of healthy latrines. The Latrine is a means of disposal of faeces where the stool is stored in a certain place so that it does not pollute the environment, does not cause disease and does not interfere with aesthetics [12]. The ownership of healthy latrines of the people who live along the river banks is still very lacking. Owned latrines are generally only in the form of small cubicles made of wood, built above the river and not equipped with a septic tank so that the waste that is discharged goes directly into the river body and pollutes the river. The condition of the latrine can be seen in figure 3 .

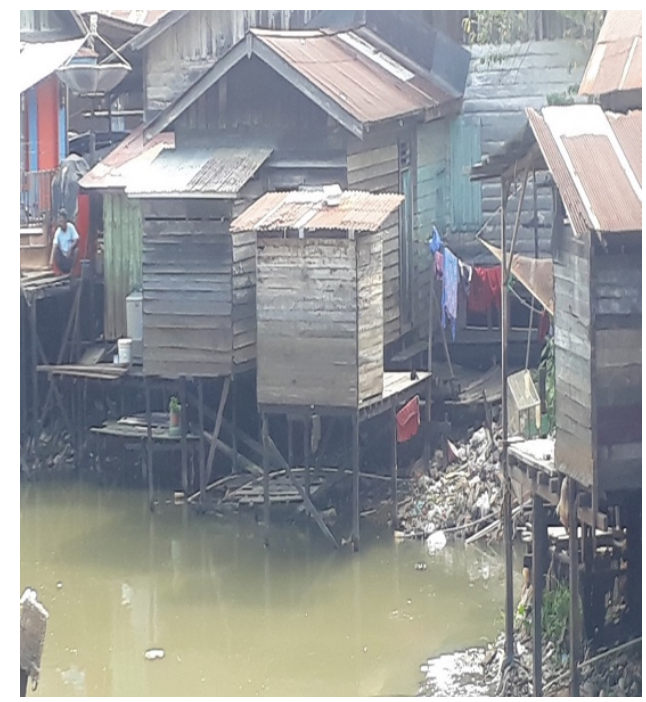

become a source of environmental pollution. Arisanty [13] states that the number of latrines affects bacterial content. High latency density causes high levels of faecal coliform bacteria.
The condition of the latrines of the people in the area did not meet the requirements of a healthy latrine. Healthy latrines must have strong buildings so they can provide security and privacy and have a septic tank so they do not 
Besides, the presence of bacteria is also influenced by the volume of water. This is consistent with Adrianto [14] which states that when the volume of water is high the bacterial content is not as big as when the water volume decreases. The volume of Karang Mumus river water at the time of sampling is quite high because at that time it entered the rainy season. So, it can be concluded that if the volume of water in the Karang Mumus River is low, then the number of bacteria found will be higher.

\section{CONCLUSION}

Based on the Environmental Protection Agency's Standard that out of 8 sample points, $37.5 \%$ did not meet the surface water-full body contact requirements and $100 \%$ did not meet the requirements for consumption. It can be concluded that the Karang Mumus River water is not suitable for sanitation and consumption purposes. The results of this study can be used as a basis for local government policymaking to address the problem of Karang Mumus river water pollution so that the degree of public health is improved.

\section{ACKNOWLEDGMENT}

The author thanks the Ministry of Research, Technology and Higher Education for funding this research and for all parties involved both technically and non-technically.

\section{REFERENCES}

[1] Litbang, "Air Sungai di Indonesia Tercemar Berat," 2015.

[2] V. Pramaningsih and S. Suprayogi, "Kajian Persebaran Spasial Kualitas Air Sungai Karang Mumus , Samarinda , Kalimantan Timur," vol. 7, no. 3, pp. 211-218, 2017.
[3] N. Z. E. reporting Series, "River water quality bacteria (Escherichia coli)." Environmental Indicators, New Zealand, 2015.

[4] Centers for Disease Control and Prevention, "E. coli (Escherichia coli)." 2014.

[5] C. Rock and B. Rivera, "Water Quality, E. coli and your HealtH,” no. March, 2014.

[6] N. Z. E. R. Series, Our fresh water 2017. 2017.

[7] M. U. Genisa and L. Auliandari, "Sebaran Spasial Bakteri Koliform di Sungai Musi Bagian Hilir," vol. 35, no. 3, pp. 131-138, 2018.

[8] P. Hatifah, A. Anwar, and Risva, "Faktor - Faktor Yang Berhubungan dengan Kualitas Bakteriologis E . Coli Sungai Karang Mumus Serta Gejala Diare Pada Balita di Kelurahan Bandara Kecamatan Sungai Pinang Kota Samarinda,” 2018.

[9] U. S. E. P. Agency, "Water Quality Standards for Coastal and Great Lakes Recreation Waters," 2004.

[10] UNESCO, “A Definition of Waste.” 2010.

[11] A. Syaiful, A. Dwi, and F. Fajarwati, "The Brantas River is Polluted." 2018.

[12] B. P. Statistik, "Indonesia - National SocioEconomic Survey 2015 September ( Social Culture Education Module) - variable - V247.” 2015.

[13] D. Arisanty, S. Adyatma, and N. Huda, "Analisis Kandungan Bakteri Fecal Coliform pada Sungai Kuin Kota Banjarmasin,” vol. 1790, 2017.

[14] R. Adrianto, "Pemantauan Jumlah Bakteri Coliform Di Perairan Sungai Provinsi Lampung," vol. 10, no. 1, pp. 1-6, 2018. 